\title{
Variation in Plant Functional Traits along Altitudinal Gradient and Land Use Types in Sagarmatha National Park and Buffer Zone, Nepal
}

\author{
Srijana Shah ${ }^{1,2 *}$, Krishna Kumar Shrestha ${ }^{2,3}$, Christoph Scheidegger ${ }^{4}$ \\ ${ }^{1}$ Department of Plant Resources, National Botanical Garden, Kathmandu, Nepal \\ ${ }^{2}$ Central Department of Botany, Tribhuvan University, Kathmandu, Nepal \\ ${ }^{3}$ Ethnobotanical Society of Nepal (ESON), Kathmandu, Nepal \\ ${ }^{4}$ Swiss Federal Institute of Forest, Snow and Landscape Research (WSL), Birmensdorf, Switzerland \\ Email: *shah.srijana@yahoo.com
}

How to cite this paper: Shah, S., Shrestha, K.K. and Scheidegger, C. (2019) Variation in Plant Functional Traits along Altitudinal Gradient and Land Use Types in Sagarmatha National Park and Buffer Zone, Nepal. American Journal of Plant Sciences, 10, 595-614.

https://doi.org/10.4236/ajps.2019.104043

Received: January 26, 2019

Accepted: April 23, 2019

Published: April 26, 2019

Copyright $\odot 2019$ by author(s) and Scientific Research Publishing Inc. This work is licensed under the Creative Commons Attribution International License (CC BY 4.0).

http://creativecommons.org/licenses/by/4.0/

\begin{abstract}
Functional traits are predictors of plants in response to environmental stimuli. They represent specific functional adaptations to various environmental stresses. This study deals with the variation in plant functional traits along elevation gradient and land-use types in Sagarmatha National Park and Buffer Zone, Nepal. Two field investigations in April and September, 2011 were made to collect samples. Sampling was done from $2200-3800 \mathrm{~m}$ asl varying approx. $400 \mathrm{~m}$. East and west facing aspects of each valley were chosen. In each aspect four land-use type categories including disturbed (cultivated land, exploited forest and meadow) and less disturbed natural forest were selected. A transect of $25 \mathrm{~m}$ long and $2.5 \mathrm{~m}$ wide was laid. Different eight traits of plants including lifeform, plant height, clonality, spinescence, leaf dry matter content, stem specific density, twig dry matter content and twig drying time were examined for 60 plant species belonging to 31 families, collected from 40 sampled plots. Nine different types of growth forms were recorded. Plant height of the investigated species ranged from $0.03-15 \mathrm{~m}$. The stolon consisting species were dominant in exploited forests. Diversity of clonal species was more in meadow and non-clonal species were dominant in all the altitudes. Only eight species consisted of spines. In the disturbed land-use categories, we found high variation in a particular trait. Correlation analyses revealed the significant relationship $(\mathrm{p}<0.01)$ among different traits. Herbs and shrubs were dominant at higher elevation and in disturbed land-use categories. Species from high altitude were mostly short basal herbs, while
\end{abstract}


spinescence and tall trees were observed at lower altitudes. Species recorded in meadows and exploited forests showed high variation in traits due to disturbance mainly grazing, fire, litter collection and trampling. Altitudinal variation, climatic conditions and disturbance most strongly influence trait expression in the study area.

\section{Keywords}

Functional Traits, Altitudinal Gradient, Land-Use Types, Disturbances

\section{Introduction}

Functional traits are those properties of an organism or a part of an organism which strongly influences fitness through their effects on growth, reproduction and survival [1]. They are biological attributes of a species that respond to the environmental conditions or processes in an ecosystem [2] [3]. Plant eco-physiological traits are clearly linked with biotic interactions involving plants, and ecosystem level properties and processes [4]. Traits are expressed in response to the influence of biotic and abiotic factors [1]. Plant functional trait (PFT) are therefore very useful in predicting changes in vegetation and biodiversity as an effect of environmental and disturbance changes and land-use shifts at regional and global scales [5]. The presence, abundance and diversity of PFT including morphological, eco-physiological and life history characteristics could be used for estimating particular components of biodiversity and together form a term called "functional indicators of biodiversity" [6]. Important questions can be answered effectively beginning with a thorough understanding of how and why key "functional" traits are related, and how these traits affect ecological outcomes such as where a species grows best and where it is most competitive [7]. Single traits cannot be the only basis for predicting vegetation changes. So, a functional analysis between key traits is necessary [8].

\subsection{Species Traits and Elevation Gradient}

Functional attributes including physiological, life history and ecological traits are directly related to variation in elevation that change with climatic factors as well as land area surface. Temperature, air pressure, and solar radiation are the climatic factors that vary with elevation influencing on the distribution of species [9]. Elevation, slope inclination and aspect exposition are the topographic factors playing an important role in determining the abundance of PFTs. Elevation is a complex combination of related climatic variables closely correlated with numerous other environmental properties like soil texture, nutrients, substrate stability and many more [10].

\subsection{Species Traits and Land-Use Types}

Land-use change includes modified and fragmented habitats, which are more 
vulnerable to invasive species and plays an important role in shaping and maintaining ecosystem structures and functions. According to [11], land-use changes involve two main impacts on the biosphere: first, the conversion (i.e. natural habitats altered for human use) and second, intensification (e.g. greater intensity and frequency of disturbance, increased use of external inputs). Habitat loss and fragmentation are the major factors which cause biodiversity loss by decreasing suitable habitats of species and thereby forcing the species to extinction [12]. Land conversion for agricultural purposes, population growth, socio-economic conditions drive land cover changes.

The present study deals with the variation in plant functional traits along the different land-use types and altitudinal gradient in Sagarmatha National Park and Buffer Zone. Further, the study aims to know the major traits the dominant plant species present in the study area; to assess variation in the traits of dominant species among major land use types; and to identify the plant species best suited for specific altitude and land-use type.

\section{Materials and Methods}

\subsection{Study Area}

Sagarmatha National Park (SNP) is located in the north-eastern part of Nepal in Solukhumbu district. SNP covers an area of $1148 \mathrm{sq} \cdot \mathrm{km}$ of Namche and Khumjung VDCs. The park is located between $27^{\circ} 46^{\prime} 19^{\prime \prime}$ to $27^{\circ} 06^{\prime} 45^{\prime \prime} \mathrm{N}$ latitudes and $86^{\circ} 30^{\prime} 53^{\prime \prime}$ to $86^{\circ} 99^{\prime} 08^{\prime \prime} \mathrm{E}$ longitudes. The buffer zone was declared in January 1 , 2002, with an area of $275 \mathrm{sq} \cdot \mathrm{km}$ [13]. This study has been carried out starting from Surkey $(2200 \mathrm{~m})$ upto Khumjung $(3800 \mathrm{~m})$. Annual precipitation occurs in the monsoon season from June to September, maximum in the July and the remainder of the year is fairly dry. Annual precipitation is $984 \mathrm{~mm}$ in Namche Bazar, $733 \mathrm{~mm}$ in Khumjung and $1043 \mathrm{~mm}$ in Tengboche. The mean temperature of the coldest month, February is $-0.11^{\circ} \mathrm{C}$. Mainly from July to August, the average annual rainfall is approximately $100 \mathrm{~mm}$. Figure 1 reveals the map of the study area.

\subsection{Study Design}

Two field investigations at April and September in 2011 were made for collecting samples. Sampling was done from $2200-3800 \mathrm{~m}$ asl varying approx. $400 \mathrm{~m}$. Two different aspects (east and west facing) of each valley were chosen. In each aspect four land-use types were selected. A transect of $25 \mathrm{~m}$ long and $2.5 \mathrm{~m}$ wide was laid [14]. Eight plant functional traits were examined for 60 plant species belonging to 31 families, collected from 40 sampled plots. Eight functional traits i.e. Growth form, plant height, clonality, spinescence, leaf dry matter content, stem specific density, twig dry matter content, twig drying time were conducted and analysed.

Land-use types category included four different types namely, Natural forest, Exploited forest, Meadows and Cultivated land [14]. Natural forests are area 


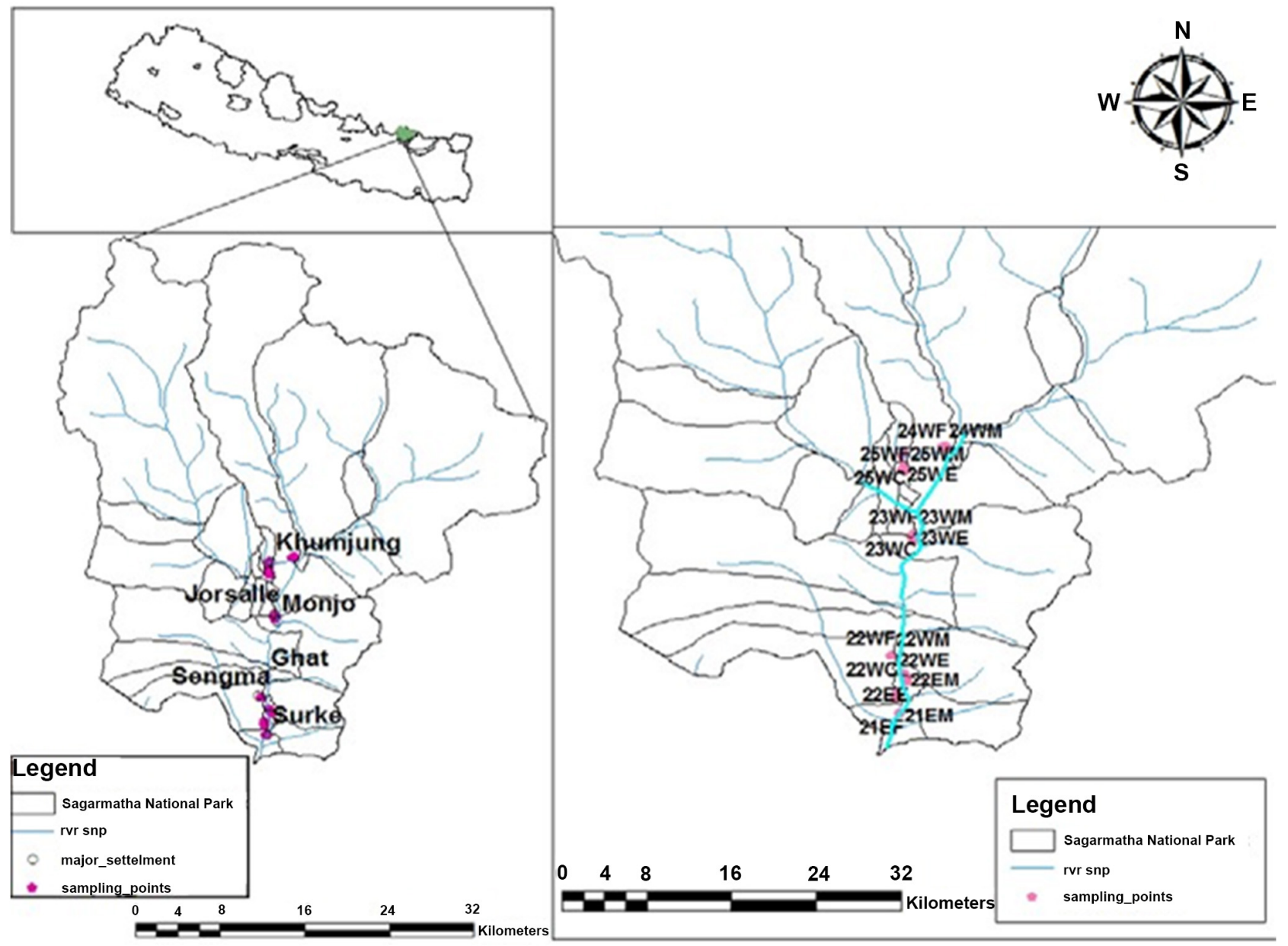

Figure 1. Map of the study site.

with either pristine character or with a low anthropogenic influence. Exploited forests are areas with a relatively closed canopy but with an altered stand structure and tree species composition compared to natural forests, either because of intensive exploitation for agriculture, livestock, and collection of fodder and fuel woods or plantation after intensive domestic or commercial forest management. Meadows are open grasslands with less than $20 \%$ tree coverage. Cultivated lands are intensively managed, fertilized, sometimes irrigated and yearly ploughed areas.

For Laboratory techniques, the protocol for standardized and easy measurement of plant functional traits worldwide [15] was followed. Functional traits were either directly measured in the forest, at the research station in the evening after collecting, in the laboratory or deduced later from measured traits.

\subsubsection{Selection of Plants}

Selection of species in a community or ecosystem: The most abundant species present in high number were chosen by counting the individuals. In forest and other predominantly woody vegetation, the most abundant species of the lower (shrub or herb) vegetation were also selected, even if their biomass was 
much lower than that of the woody species.

Selection of individuals within a species: Well grown plants, preferably of unshaded condition were chosen. Plants strongly affected by herbivores or pathogens were ignored. Fresh and dry weights of the plants were measured by using weighing machine.

Identification of selected species: The species in the field were identified by observation by researchers, taxonomist and field members consulting pictorial plant identification book like Flowers of Himalayas and its supplement. The species were tagged, for further confirmation by cross tallying with specimen deposited at National Herbarium and Plant Laboratories (KATH), Godawari and Tribhuvan University Central herbarium (TUCH), Kritipur.

\subsubsection{Plant Traits Measurement}

1) Vegetative traits:

a) Growth form: Species were assigned as: Short basal, long basal, semi basal, erect leaf, cushions, tussocks, dwarf shrubs, shrubs, trees, palmoids, and climbers and scramblers.

b) Plant height: For herbaceous plants the height was measured using the measuring tape, in meters. For tree height, clinometer was used.

c) Clonality: It is the ability of a plant to reproduce itself vegetatively, thereby producing new ramets (underground units) and expanding horizontally. Species were assigned as Non-clonal, clonal aboveground and clonal belowground.

2) Spinescence:

A spine is usually a pointed modified leaf, leaf part or stipule. The type, size and density of spines, thorns and/or prickles play an obvious role in antiherbivore defense.

\section{3) Leaf traits:}

Leaf dry matter content (LDMC) is an estimate for plant tissue density. Fresh weight of each leaf was taken and tagged. And dried in an oven at $60^{\circ} \mathrm{C}$ for 72 hrs and reweighted for dry mass. It was calculated by dividing Oven dry wt. of leaf (mg) by Fresh wt. (gm).

4) Stem traits:

a) Stem specific density (SSD): SSD = Oven dry mass of the stem (mg)/Volume of the stem when fresh $\left(\mathrm{mm}^{3}\right)$. Oven dry mass of a section of a plant's main stem was taken drying the stem at $60^{\circ} \mathrm{C}$ for $72 \mathrm{hrs}$. For calculating the volume of very thin stem, Volume of the fresh stem $=(0.5$ Diameter of the stem $) 2 \times \pi \times$ Length of the stem formula was used.

b) Twig dry matter content (TDMC): 1 - 3 terminal twigs of $20 \mathrm{~cm}$ long from five individuals of dominant trees and shrubs were collected. Fresh mass of the twig was taken and oven dried at $40^{\circ} \mathrm{C}$. In every 24 hour, each sample was reweighed. TDMC $=$ Oven-dry mass (mg) of a terminal twig/Fresh mass (gm).

c) Twig drying time: It is defined as the number of days a twig takes to dry out completely. In each 24 hours dry mass of twig was measured to see the decrease in weight unless there was no further decrease. 


\subsection{Statistical Analyses}

For analyses of quantitative traits, the overall data was divided into three growth forms (i.e. herb, shrub and tree). Each trait was then tested to find significant difference with land-use types and altitude for three growth forms. After a normality test (Shapiro Wilk), traits such as plant height, LDMC and SSD of herbs and shrubs were square root transformed to meet the normality assumption while the remaining data was considered normal and left untransformed.

One-way Analysis of Variance (ANOVA) was used to find the variability across means of quantitative traits with land-use types and altitude. Post hoc analysis (Tukey's HSD test) at $5 \%$ level of significance was carried out within the results of ANOVA to find more pairwise significant difference of traits with environmental variables. ANOVA was also used to find the altitude wise variation in quantitative traits along different land-use types. Spearman's correlation was done to test the relationship among functional traits in overall altitude and to explore the relationship among functional traits for each five altitude. ANOVA was performed using statistical computer program $\mathrm{R}$ version 2.12.1. Correlation was done in SPSS Statistics 17.0.

\section{Results}

Sixty dominant species belonging to 31 families including five gymnosperms were selected in the 40 sampled plots (see in Appendix for the list of investigated plant species) of which 28 species were also observed in other altitudinal as well as land-use gradients (for example; Rhododendron arboreum, R. lepidotum, Artemesia vulgaris, Pinus wallichiana, Senecio diversifolia). Hence, categorical traits were determined for the repeated species also. The plant communities examined in the present study were composed of trees, shrubs, dwarf shrubs and herbs. The number of the investigated dominant species ranged from $2-3$ per transect.

\subsection{Growth form along Land-Use Type and Altitude}

Nine different types of growth forms were recorded from the study site. The plant species collected (both dicots and monocots) included 12 trees, 19 shrubs, 28 herbs and 1 climber. The herbaceous plants included 5 short basal, 1 long basal, 1 semi basal, 13 erect leafy, 3 tussocks and 5 palmoid. The most abundant form was the herbaceous erect leafy followed by trees and shrubs. Trees were dominant in natural forest. Short basal and erect leafy herbs were found to be dominant on meadow. The number of shrubs was higher in the exploited forest in comparison to other land-use types (Figure 2(a)). Along the altitudinal gradient, trees and erect leafy herbs decreased in number in comparison to other growth forms. Dwarf shrub and tussocks were dominant at $3400 \mathrm{~m}$ (Figure 2(b)).

\subsection{Plant Height}

Plant height of the investigated species ranged from $0.03-15 \mathrm{~m}$. Among the 


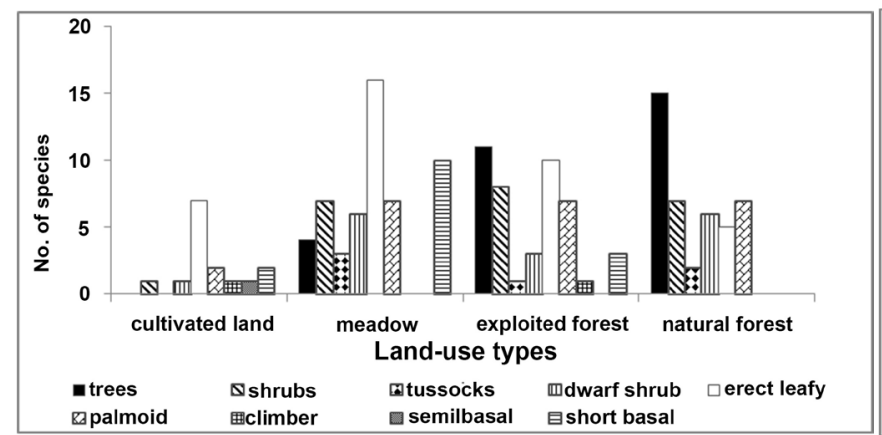

(a)

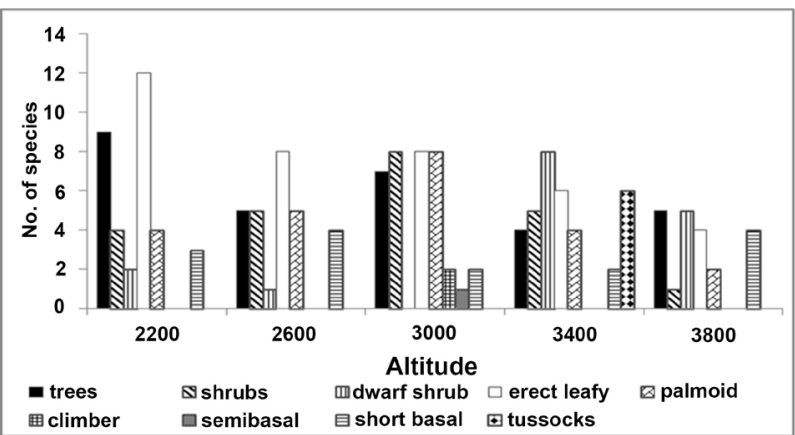

(b)

Figure 2. Distribution of different growth forms along (a) land-use types and, (b) altitudinal gradient.

herb and shrub species, height showed highly significant difference with altitude. Height of the tree species showed significant difference with land-use type and altitude (Table 1). From post hoc analysis, significant difference was observed between meadow and natural forest $(\mathrm{p}<0.01)$. Outlier was observed at $3000 \mathrm{~m}$ showing the highest height of herb. Herb height showed the lowest value at $3800 \mathrm{~m}$ with outlier (Figure 3(a)). Shrub height showed the lowest value at $2600 \mathrm{~m}$ and the highest value at $3000 \mathrm{~m}$ and $3800 \mathrm{~m}$ (Figure 3(b)). Taller tree was present at natural forest and tree with less height were observed in meadows (Figure 3(c)).

\subsection{Clonality}

The stolon consisting species such as Anaphalis busua, Androsacae sarmentosa, Fragaria nubicola, and $F$. indica were dominant in exploited forest. Diversity of clonal species was more in meadow (Figure 4(a)). Non-clonal species were dominant in all the altitudes. At $3400 \mathrm{~m}$, stolon, bulb and adventitious bud forming species were dominant. At $2200 \mathrm{~m}$, non-clonal species were most dominant followed by stolon and vegetative bud forming species (Figure 4(b)). Species with vegetative buds were Arundinaria maling, Impatiens urticifolia and Rosa sericea; and others clonal belowground were Commelina maculata, Iris clarkei, Malaxis cylindristachya, Senecio diversifolius and Rumex nepalensis.

\subsection{Spinescence}

Among the investigated species, only eight consisted of spines. The species with longer spines were dominant mostly at the meadows (Figure 5(a)). In comparison to lower altitude, spine consisting species decreased at highest altitude (Figure 5(b)). Spinescence was observed in Berberis aristata, Cotoneaster microphyllus, Dipsacus inermis, Rosa sericea, and Zanthoxylum armatum, occurring at the meadow whereas Rubus ellipticus and Quercus semecarpifolia were occurred at the natural forests.

\subsection{Leaf Dry Matter Content (LDMC)}

The highest LDMC was recorded in Rhododendron arboreum $(736.360 \mathrm{mg} / \mathrm{g}$ ) followed by Pinus wallichiana, Quercus semecarpifolia and Abies spectabilis 
Table 1. Results of One-way ANOVA of height of herbs, shrub and tree species.

\begin{tabular}{|c|c|c|c|c|c|c|}
\hline & & Herbs & & Shrubs & & Trees \\
\hline Df & F value & p-value & F value & $\mathrm{p}$-value & F value & $\mathrm{p}$-value \\
\hline LUT 3 & 1.2112 & 0.3055 & 1.6977 & 0.1695 & 11.775 & $<0.001^{* * *}$ \\
\hline Altitude 4 & 15.365 & $<0.001^{\star * *}$ & 7.516 & $<0.001^{* * *}$ & 4.8228 & $0.03071^{*}$ \\
\hline
\end{tabular}

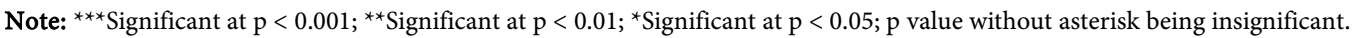

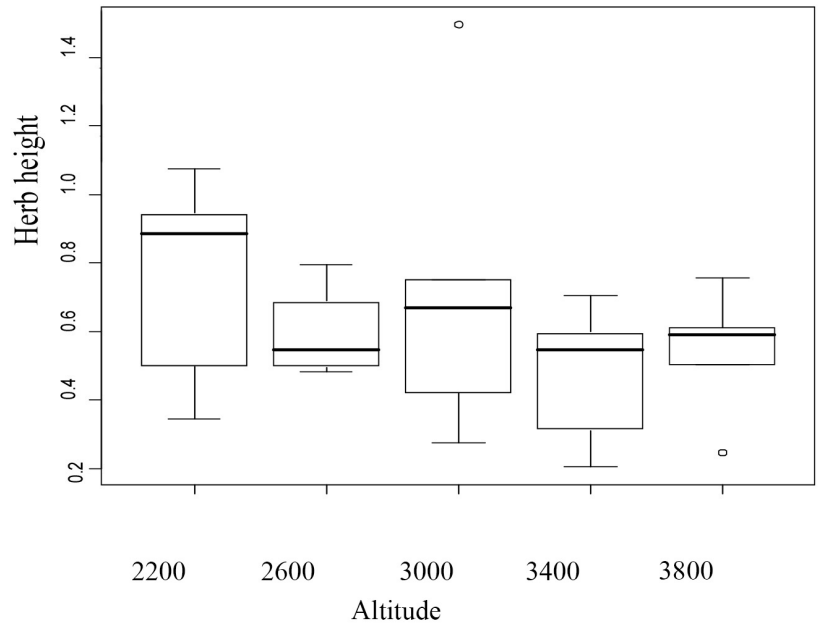

(a)

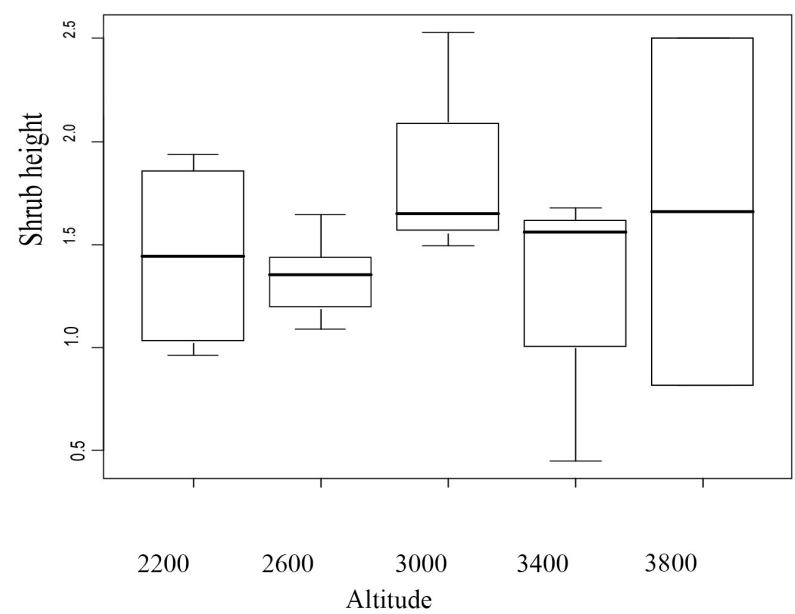

(b)

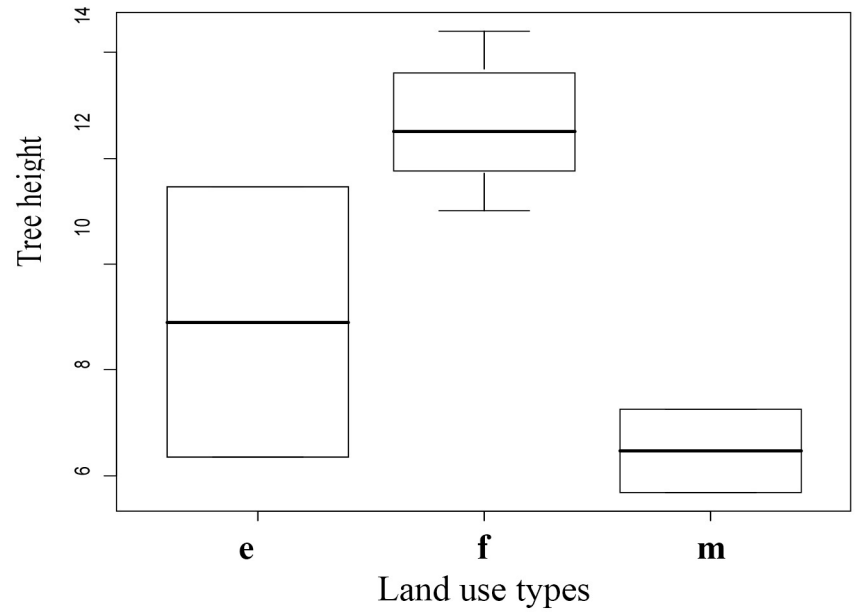

(c)

Figure 3. Box-plot showing relationship between (a) herb height along altitude, (b) shrub height along altitude and, (c) tree height in different land use types. The dark line in the box plot represents the median or mid value and its arm represents the quartile value. e represent exploited forest, $\mathrm{f}$ for natural forest and $\mathrm{m}$ as meadow.

while the lowest LDMC was of Pilea umbrosa ( $35 \mathrm{mg} / \mathrm{g}$ ). LDMC of herb was significant with land-use type. From post hoc analysis, significant difference ( $\mathrm{p}<$ 0.01 ) was found in natural and exploited forest. LDMC of shrub was found significantly different with altitude. Similarly, LDMC of trees showed significant difference with land-use type and altitude (Table 2). Lowest LDMC of tree was 


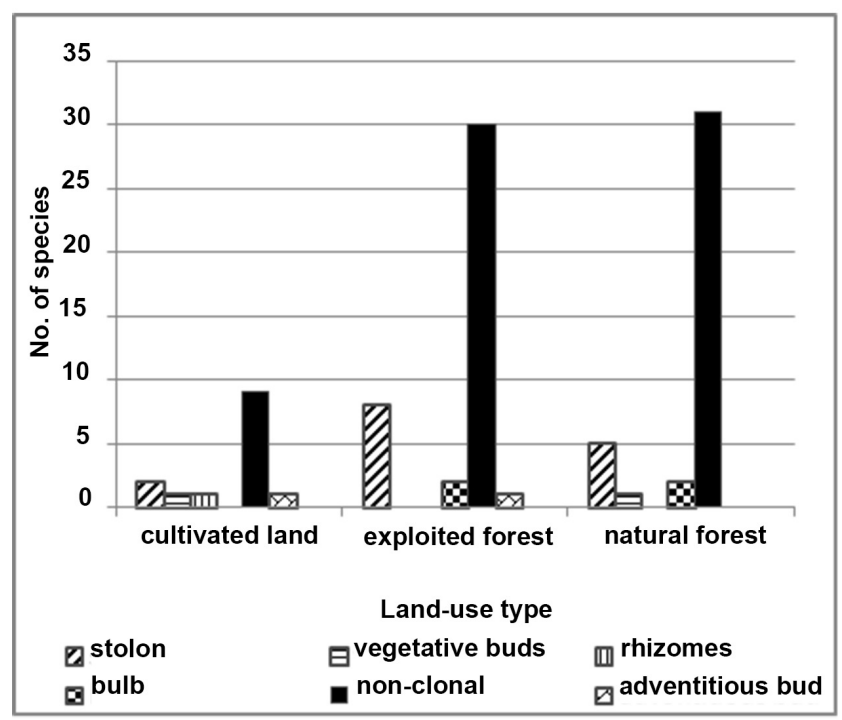

(a)

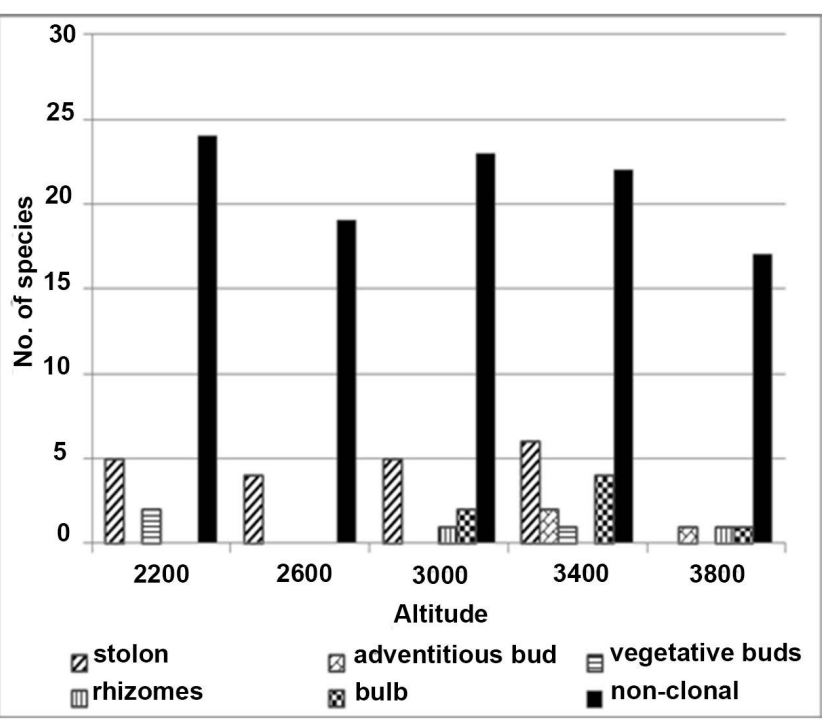

(b)

Figure 4. Distribution of different clonality categories along (a) land-use types and, (b) altitudinal gradient.

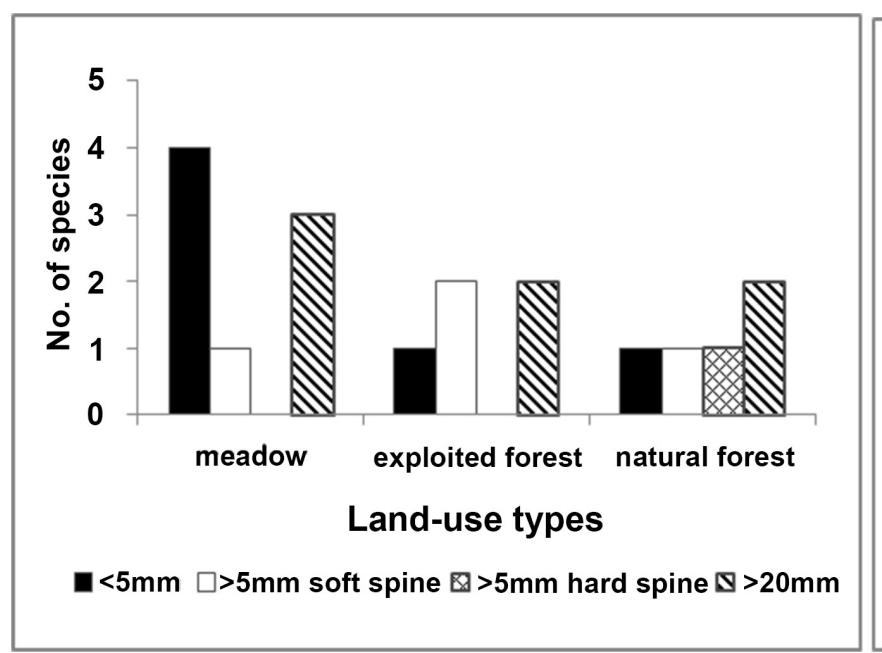

(a)

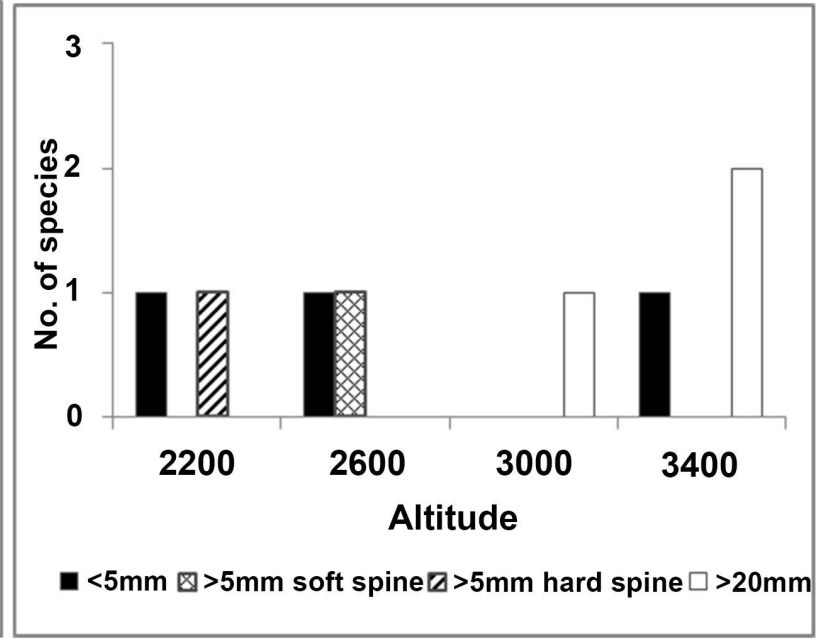

(b)

Figure 5. Distribution of spines in various (a) land-use types and, (b) altitudinal gradient.

Table 2. Results of One-way ANOVA of LDMC of herbaceous, shrub and tree species.

\begin{tabular}{|c|c|c|c|c|c|c|c|}
\hline & & & Herbs & & Shrubs & & Trees \\
\hline & Df & F value & $\mathrm{p}$ value & F value & $\mathrm{p}$ value & F value & $\mathrm{p}$ value \\
\hline Land-usetype & 3 & 3.5342 & $0.0150^{*}$ & 0.5483 & 0.65 & 10.695 & $<0.001^{\star * *}$ \\
\hline Altitude & 4 & 0.9735 & $<0.001^{\star * *}$ & 0 & $<0.001^{\star * *}$ & 9.525 & $0.0027^{\star \star}$ \\
\hline
\end{tabular}

Note: ${ }^{* *}$ Significant at $\mathrm{p}<0.001 ;{ }^{*}$ Significant at $\mathrm{p}<0.01 ;{ }^{*}$ Significant at $\mathrm{p}<0.05 ; \mathrm{p}$ value without asterisk being insignificant.

observed in natural forest (Figure 6(a)). Highest value of shrub LDMC was observed at $2600 \mathrm{~m}$ with outliers and the lowest value at $3400 \mathrm{~m}$ (Figure 6(b)). Highest value of herb LDMC was observed at $3400 \mathrm{~m}$ and lowest at $2200 \mathrm{~m}$ with outliers (Figure 6(c)). 


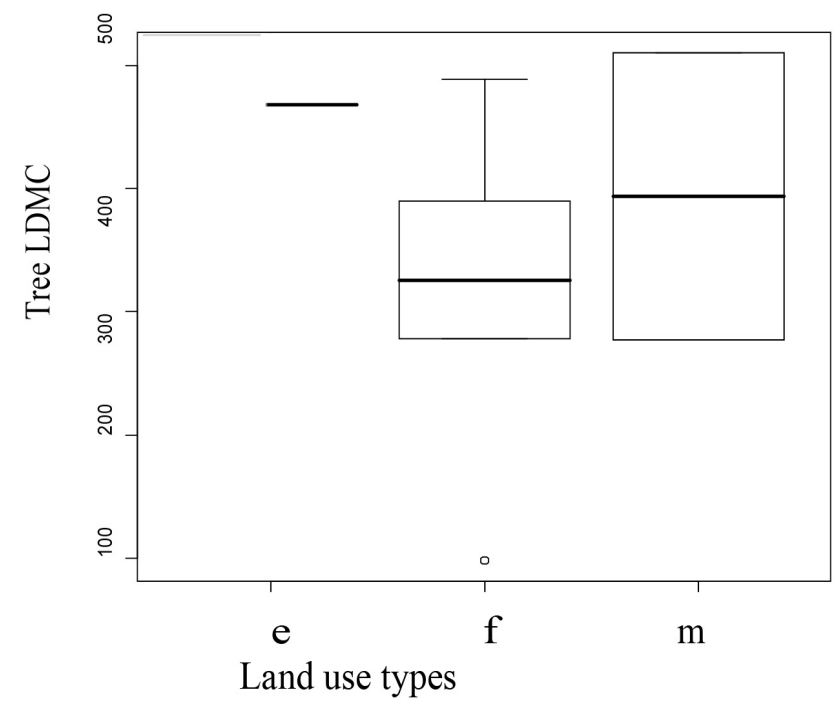

(a)

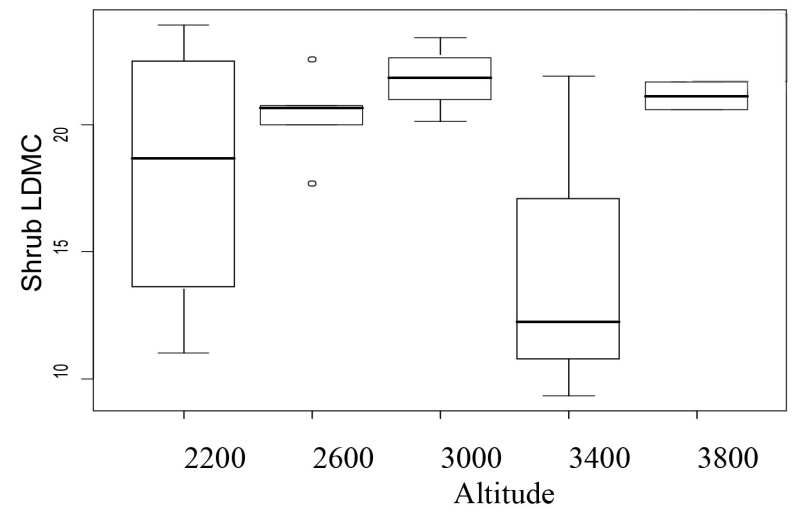

(b)

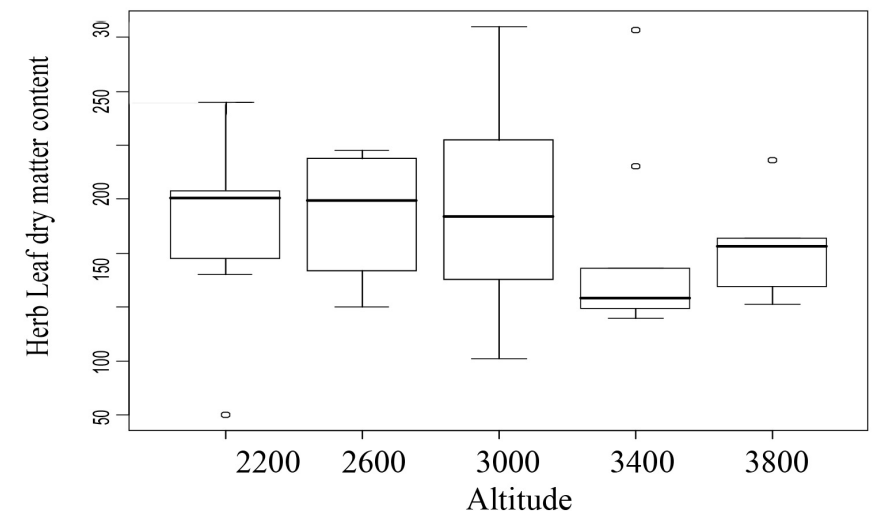

(c)

Figure 6. Box-plot showing relationship between (a) tree LDMC along land use types (b) shrub LDMC along altitude and, (c) herb LDMC along altitude. e represents exploited forest, $\mathrm{f}$ for natural forest and $\mathrm{m}$ as meadow.

\subsection{Stem Specific Density (SSD)}

Altogether 27 trees and shrub species were collected and among them stem specific density of 15 shrubs were measured. The highest value of SSD was recorded in Rhododendron lepidotum $\left(9.35 \mathrm{mg} / \mathrm{mm}^{3}\right)$ while the lowest value was observed in Anaphalis busua $\left(0.19 \mathrm{mg} / \mathrm{mm}^{3}\right)$. Stem specific density for herbs showed significant difference with land-use type (Table 3 ). More difference was seen in between exploited forest and cultivated land $(\mathrm{p}<0.001)$ as well as natural forest and exploited forest $(\mathrm{p}<0.001)$ from post hoc analysis. Similar result was observed from boxplot showing lowest value of SSD at exploited and natural forest with presence of outliers and highest value at natural forest (Figure 7).

\subsection{Twig Dry Matter Content (TDMC)}

Twig dry matter content was calculated for tree and shrubs. The highest value of TDMC was $875 \mathrm{mg} / \mathrm{gm}$ in Gaultheria fragrantissima, while the lowest was 251.57 $\mathrm{mg} / \mathrm{gm}$ in Abies spectabilis. TDMC of shrub species was found significant with 
Table 3. Results of One-way ANOVA of SSD of herbaceous and shrub species.

\begin{tabular}{|c|c|c|c|c|c|}
\hline \multirow{2}{*}{\multicolumn{2}{|c|}{ Land-usetype Df }} & \multicolumn{2}{|c|}{ Herbs } & \multicolumn{2}{|c|}{ Shrubs } \\
\hline \multirow{2}{*}{ Land-usetype } & & F value & $\mathrm{p}$ value & F value & $\mathrm{p}$ value \\
\hline & 3 & 10.100 & $<0.001^{\star * *}$ & 1.5936 & 0.1979 \\
\hline Altitude & 4 & 0.0875 & 0.7677 & 3.2544 & 0.0751 \\
\hline
\end{tabular}

Note: ${ }^{* *}$ Significant at $\mathrm{p}<0.001$; ${ }^{* *}$ Significant at $\mathrm{p}<0.01$; ${ }^{*}$ Significant at $\mathrm{p}<0.05$; $\mathrm{p}$ value without asterisk being insignificant.

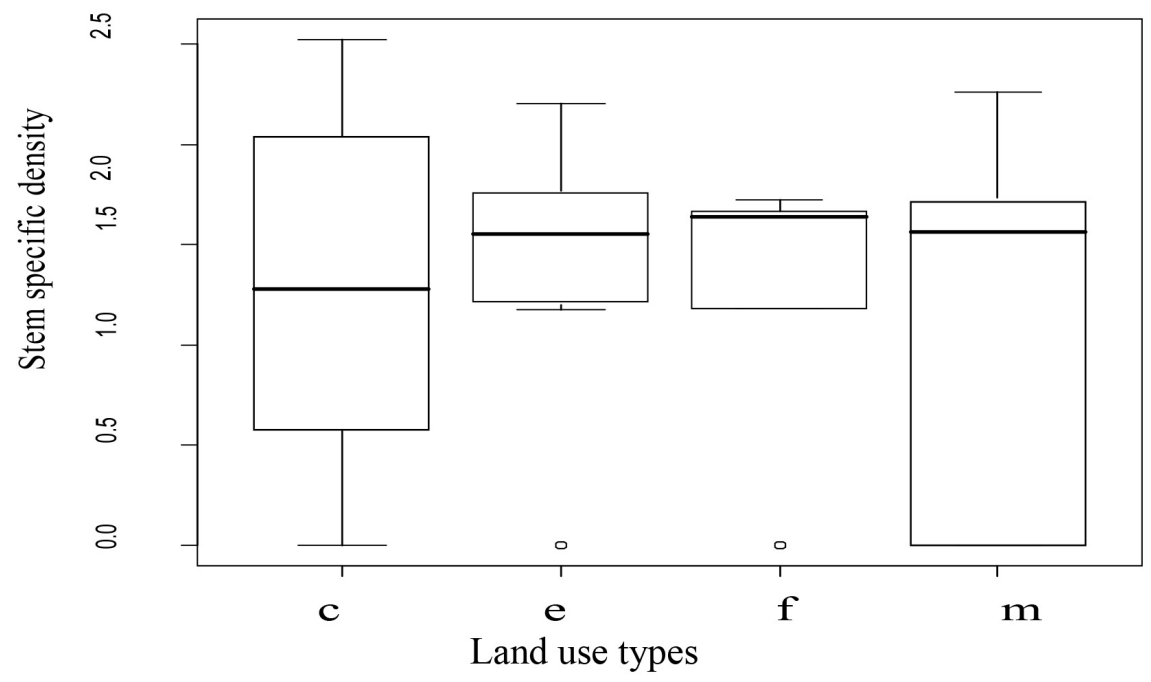

Figure 7. Box-plot showing relationship between stem specific density in different land use types. $\mathrm{c}$ represents cultivated land, e is exploited forest, $\mathrm{f}$ for natural forest and $\mathrm{m}$ as meadow.

land-use and altitude (Table 4). More difference was found between meadow and exploited forest. Similarly, twig dry matter content for trees showed significant difference with land-use type (Table 4). Outlier was present showing the highest value of tree TDMC at the natural forest and lowest mean value was observed at meadow (Figure 8).

\subsection{Twig Drying Time}

There was not much difference in the twig drying time of the plant species. TDT ranged from $2-4$ days. The twigs of Juniperus indica, Pieris formosa, Pinus wallichiana and Quercus semecarpifolia dried in 4 days, while Osbekia took the lowest drying time i.e. 2 days. All the other remaining species took 3 days to dry out completely.

\subsection{Correlation between Traits}

Spearman's Correlation Analysis revealed significant relationships among a number of traits (Table 5). Significant correlation $(\mathrm{p}<0.01)$ were observed between Plant height and LDMC $(r=0.553)$, Plant height and SSD $(r=0.462)$, Plant height and TDMC $(r=0.802)$, Plant height and TDT $(r=0.801)$, LDMC and TDMC $(r=0.610)$, LDMC and TDT $(r=0598$.$) , SSD and TDMC (r=$ $0.371)$, SSD and TDT $(r=0.426)$, and TDMC and TDT $(r=0.976)$. 
Table 4. Results of One-way ANOVA of TDMC of shrub and tree species.

\begin{tabular}{ccclcc}
\hline & & \multicolumn{3}{c}{ Shrubs } & Trees \\
\hline & Df & F value & p value & F value & p value \\
\hline Land-usetype & 3 & 6.6064 & $0.002^{* *}$ & 9.5956 & $<0.001^{* * *}$ \\
Altitude & 4 & 11.999 & $0.001^{* *}$ & 1.6489 & 0.2058 \\
\hline
\end{tabular}

Note: ${ }^{* *}$ Significant at $\mathrm{p}<0.001 ;{ }^{*}$ Significant at $\mathrm{p}<0.01$; ${ }^{*}$ Significant at $\mathrm{p}<0.05$; $\mathrm{p}$ value without asterisk being insignificant.

Table 5. Correlation coefficient between different traits of overall altitudes (values with bold entries showed statistically significant).

\begin{tabular}{cccccc}
\hline & Plant height & LDMC & SSD & TDMC & TDT \\
\hline Plant height & 1.000 & & & & \\
LDMC & $\mathbf{0 . 5 5 3 ^ { * * }}$ & 1.000 & & & \\
SSD & $\mathbf{0 . 4 6 2 ^ { * * }}$ & .236 & 1.000 & & \\
LDMC & $\mathbf{0 . 8 0 2 ^ { * * }}$ & $\mathbf{0 . 6 1 0 ^ { * * }}$ & $\mathbf{0 . 3 7 1 ^ { * * }}$ & 1.000 & \\
TDT & $\mathbf{0 . 8 0 1 ^ { * * }}$ & $\mathbf{0 . 5 9 8 ^ { * * }}$ & $\mathbf{0 . 4 2 6 ^ { * * }}$ & $\mathbf{0 . 9 7 6 ^ { * * }}$ & 1.000 \\
\hline
\end{tabular}

Note: ${ }^{* *}$ Correlation significant at $\mathrm{p}<0.01$; ${ }^{*}$ significant at $\mathrm{p}<0.05$; other correlations being insignificant.

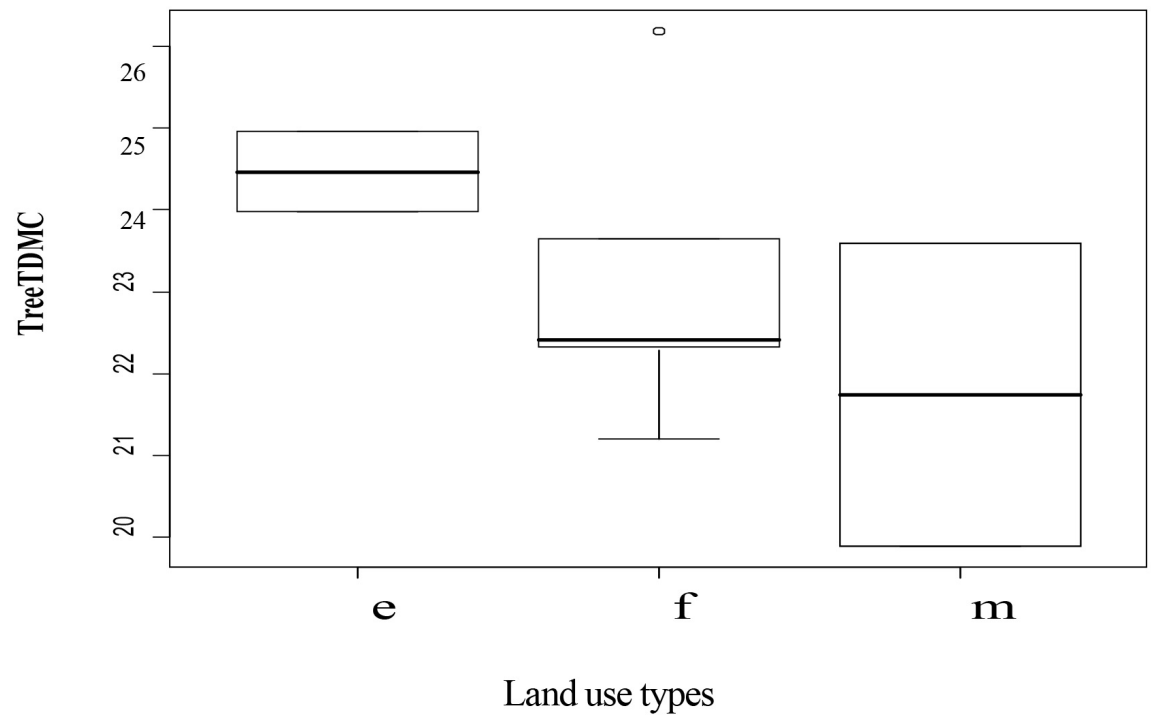

Figure 8. Box-plot showing relationship between tree TDMC in different land-use types.

The correlation coefficient value showed significantly different result within same altitudes as well as other altitudes. Along each of the five altitudinal gradients, plant height showed positive correlation with TDMC and TDT. Higher significant correlation between traits was found in the lower altitude $(2200 \mathrm{~m})$. LDMC also showed positive correlation with TDMC and TDT at $2200 \mathrm{~m}$ and $2600 \mathrm{~m}$.

\section{Discussion}

\subsection{Growth form along Land-Use Type and Altitude}

The result achieved shows variation in different traits along altitude as well as 
land-use types. Among the various growth forms, tree was dominant in natural forest while different categories of herbs were less dominant. This might be because herbs do not grow well under canopy due to difficulty in light intensity much reaching to the ground [16] [17]. Shrubs and erect leafy were found to be dominant at meadow and exploited forest which may be an adaptation to grazing. The height and positioning of the foliage may be both adaptations and responses to grazing by different herbivores [15]. Along the altitudinal gradient, tree and erect leafy herb species decreased in number whereas other herb and dwarf shrub species were found to be dominant along higher altitude. Similar result of increment in herbs at higher altitudes was found by Wana and Beierkuhnlein (2009) [18] in southwest Ethiopian highlands. The distinction of growth forms informs us about the specific adaptations to environmental conditions such as climate and wind [19] [20], solar energy partitioning [21], water use efficiency [22] and resource partitioning [23] in the ecosystem.

\subsection{Plant Height}

Herb and shrub height showed a significant difference with the altitude. A study by Bhattarai and Vetaas (2003) [24] in the Himalayan range indicates that woody species display a uni-modal pattern of diversity while herbaceous species do not show any relationship to altitude which is different from the result of present study. The reason behind it could possibly be the effect of an incomplete gradient length of the study ranging of $2200-3800 \mathrm{~m}$ asl. Plant height in case of shrubs showed significant difference between natural forest and exploited forest as well as between meadow and exploited forest. Significant difference was observed with land-use types mainly between meadow and natural forest in case of tree height. It may be due to the presence of very few trees of short stature in meadow, and low disturbance such as grazing, mowing, firing, etc in natural forest in comparison to the meadow. Short plants were found most dominant in the meadows because they have higher quality and growth rate, and are more tolerant to herbivory than taller plants [25].

\subsection{Clonality}

Rhizomes and other clonal species were dominant in high altitudes for adaptation to chilling and grazing, similar to the finding of Wana and Beierkuhnlein (2009) [18]. Increase of clonal species in the colder sites was also found by [26] in East Ladakh, Western Himalayas. Diversity of clonal species was high in the meadows as they grow well in harsher environment [10] and nutrient-poor conditions [27]. In response to severe environments, plants either develop adaptations that enable protection of renewing buds or spread the risk of bud mortality by multiplying buds through clonal growth [28]. Clonal behavior may also be an effective means of short distance spread under circumstances of poor seed dispersal or seedling recruitment [15].

\subsection{Spinescence}

Plant species with spines were mostly shrubs and were dominant at the meadows 
as disturbance level is high due to grazing, trampling, etc. Another reason may be defense mechanism to protect them from herbivores. They can play an additional role in reducing heat or drought stress [15] by dissipating heat loading on the surface of the leaves and stems or absorbing solar radiation, in addition to their role as a mechanical deterrence against vertebrate herbivory [29]. Spines were found to be more abundant in lower altitudinal ranges in response to drought and grazing which is similar to the findings Wana and Beierkuhnlein (2009) [18] and Dalacho (2009) [20].

\subsection{Leaf Dry Matter Content (LDMC)}

Leaf dry matter content of tree varied significantly with land-use type and altitude. Significant differences were found between meadow and cultivated land as well as natural forest and cultivated land. In the natural forest, trees with high LDMC were present while in the cultivated and meadow more herbs with low LDMC were present. Species with low LDMC are associated with highly disturbed environments, intensive land-use and colder sites [30]. At higher altitude, fast-growing and shorter species also have low LDMC and lower toughness [31]. Plants found in highlight, less intensive land-use and warmer sites usually have thick leaves with high LDMC [30] [32]. LDMC was significant with altitude in the herbaceous species. Spinescence, growth form, clonality, Twig drying time and plant height were positively correlated with LDMC.

\subsection{Stem Specific Density (SSD)}

Stem specific density for herbs showed significant difference with land-use type. More difference was observed between exploited forest and cultivated ( $\mathrm{p}<$ $0.001)$ as well as natural forest and exploited $(p<0.001)$. Trees present in the natural forest had more stem specific density than the ones present in the exploited forest. Best competitors for light are those plants that allocate large fractions of their biomass to above ground organs i.e. stems and leaves [1]. SSD is correlated with plant height and TDMC. The higher the plants are the higher is their stem density as well as twig dry matter content. A dense stem provides the structural strength that a plant needs to stand upright and the durability it needs to live sufficiently long. The lower the stem density is the higher is their plant growth rate.

\subsection{Twig Dry Matter Content (TDMC)}

Twig dry matter content of tree differed significantly with altitude and land-use type. High significance was between meadow and exploited forest. Low TDMC may be positively correlated with high potential relative growth rate. Twig drying time was positively correlated to twig dry matter content in case of trees. Twigs with high dry matter are expected to dry out relatively quickly during the dry season in fire-prone regions [15]. Highest TDMC value in this study was recorded in Gaultheria fragrantissima which indicates that it has stronger 
avoidance characteristics than the others as reported by Olivero (2011) [33].

\section{Conclusions}

Both quantitative as well as qualitative traits show a great deal of variation among different environmental gradients (altitude and land-use types). Four different land-use types exhibited a significant relationship with traits. Plant traits were found to vary significantly between disturbed (i.e. cultivated land, meadow and exploited forest) and less disturbed (natural forest). Some contrasting results found in this study pave the way towards a better understanding of how species cope with varying habitat conditions.

Both natural as well as anthropogenic disturbances are responsible for the shift of PFTs. The main disturbances were grazing, fire, trampling, litter collection, etc. Grazing favors species that are short-lived, herbaceous growth form and clonal. The study site being a Himalayan region, especially in the higher altitude a more harsher environment persist due to cold climate as well as other disturbance factors which cause less diversity of growth forms and more variation in traits. The variation in the abundance of certain plant functional traits at a particular habitat informs us about the strength of the dominant environmental constraint such as climate, resource availability and disturbance level in that ecosystem.

\section{Acknowledgements}

We are grateful to Central Department of Botany, Tribhuvan University, Nepal and Swiss Federal Institute for Forest, Snowand Landscape Research, WSL, Switzerland (CDB-WSL Project 2010-2013 and its all members Dr. Jyoti Gajurel, Dr. Shiva Devkota, Mr. Sanjeev Kumar Rai, and) for guidance, encouragement, suggestions, technical and financial support throughout the work. Dr. Chitra Bahadur Baniya, Dr. Khemraj Bhattarai and especially Dr. Suresh K. Ghimire are highly acknowledged for providing valuable suggestions in the analysis part. Cornell Nepal Study Program, Kritipur is thanked for providing partial grant. Thanks also go to my dear friends Mr. Arjun Chapagain, Mr. Hem Bahadur Katuwal, Ms. Susma Sharma and Ms.Laxmi Sankhi for helping me during and after field work.

\section{Conflicts of Interest}

The authors declare that they have no any conflict of interest.

\section{References}

[1] Minden, V. (2010) Functional Traits of Salt Marsh Plants: Responses of Morphology- and Elemental-Based Traits to Environmental Constraints, Trait-Trait Relationships and Effects on Ecosystem Properties. Ph.D. Thesis, Carl von Ossietzky University of Oldenburg, Oldenburg, Germany.

[2] Gitay, H. and Noble, I.R. (1997) What Are Functional Types and How Should We Seek Them? In: Smith, T.M., Shugart, H.H. and Woodward, F.I., Eds., Plant Func- 
tional Types. Their Relevance to Ecosystem Properties and Global Change, Cambridge University Press, Cambridge, UK, 3-19.

[3] Lavorel, S., McIntyre, S., Landsberg, J. and Forbes, T.D.A. (1997) Plant Functional Classification: From General Groups to Specific Groups Based on Response to Disturbance. Trends in Ecology and Evolution, 12, 474-478. https://doi.org/10.1016/S0169-5347(97)01219-6

[4] Wardle, D.A., Barker, G.M., Bonner, K.I. and Nicholson, K.S. (1998) Can Comparative Approaches Based on Plant Ecophysiological Traits Predict the Nature of Biotic Interactions and Individual Plant Species Effects in Ecosystems? Journal of Ecology, 86, 405-420. https://doi.org/10.1046/j.1365-2745.1998.00268.x

[5] Pausas, J., Rusch, G.M. and Leps, J. (2003) Plant Functional Types in Relation to Disturbance and Land-Use. Journal of Vegetation Science, 14, 305-422.

[6] De Bello, F., Berg, M.P., Vandewalle, M., Bolger, T., Doledec, S., Dubs, F., Feld, C.K., Harrington, R., Harrison, P.A., Lavorel, S., Da Silva, P.M., Moretti, M., Niemela, J., Santos, P., Sattler, T., Sousa, J.P., Sykes, M.T., Vanbergen, A.J. and Woodcock, B.A. (2010) Functional Traits as Indicators of Biodiversity Response to Land Use Changes across Ecosystems and Organisms. Biodiversity and Conservation, 19, 2921-2947. https://doi.org/10.1007/s10531-010-9798-9

[7] Wright, S.J., Bunker, D., Dalling, J., Davies, S., Diaz, S., Engelbrecht, B., Harm, K., Kitajima, K., Kraft, N., Marjs, C., Reich, P., Valencia, R., Wright, I. and Zanne, A. (2006) Towards a Functional Trait Based Research Program within the Center for Tropical Forest Science.

[8] Klimesova, J., Latzel, V., De Bello, F. and Van Groenendael, J.M. (2008) Plant Functional Traits in Studies of Vegetation Changes in Response to Grazing and Mowing: Towards a Use of More Specific Traits. Perslia, 80, 245-253.

[9] Becker, A., Korner, C., Brun, J.J., Guisan, A. and Tappeiner, U. (2007) Ecological and Land-Use Studies along Elevational Gradients. Mountain Research and Development, 27, 58-65. https://doi.org/10.1659/0276-4741(2007)27[58:EALUSA]2.0.CO;2

[10] Klimes, L. (2003) Life-Forms and Clonality of Vascular Plants along an Altitudinal Gradient in E Ladakh (NW Himalayas). Basic and Applied Ecology, 4, 317-328. https://doi.org/10.1078/1439-1791-00163

[11] Foley, J.A., DeFries, R., Asner, G.P., Barford, C., Bonan, G. and Carpenter, S.R. (2005) Global Consequences of Land Use. Science, 309, 570-574. https://doi.org/10.1126/science.1111772

[12] Thomas, C.D., Cameron, A., Green, R.E., Bakkenes, M., Beaumont, L.J., Collingham, Y.C., Erasmus, B.F.N., De Siqueria, M.F., Grainger, A., Hannah, L., Hughes, L., Huntley, B., Van Jaarsveld, A.S., Midgley, G.F., Miles, L., Ortega-Huerta, M.A., Peterson, A.T., Phillips, O.L. and Williams, S.E. (2004) Extinction Risk from Climate Change. Nature, 427, 145-148. https://doi.org/10.1038/nature02121

[13] United Nations Environment Programme (2008) The Encyclopedia of Earth, Washington DC.

[14] Scheidegger, C., Nobis, M. and Shrestha, K.K. (2010) Biodiversity and Livelihood in Land-Use Gradients in an Era of Climate Change-Outline of a Nepal-Swiss Research Project. Botanica Orientalis. Journal of Plant Science, 7, 7-14. https://doi.org/10.3126/botor.v7i0.4368

[15] Cornelissen, J.H.C., Lavorel, S., Garnier, E., Diaz, S., Buchmann, N., Gurvich, D.E., Reich, P.B., Steege, H., Morgan, H.D., Van Der Heijden, M.G.A., Pausas, J.G. and Poorter, H. (2003) A Handbook of Protocols for Standardized and Easy Measure- 
ment of Plant Functional Traits Worldwide. Australian Journal of Botany, 51, 335-380. https://doi.org/10.1071/BT02124

[16] Whittaker, R.J., Willis, K.J. and Field, R. (2001) Scale and Species Richness: Towards a General, Hierarchical Theory of Species Diversity. Journal of Biogeography, 28, 453-470. https://doi.org/10.1046/j.1365-2699.2001.00563.x

[17] Panthi, M., Chaudhary, R.P. and Vetaas, O.R. (2007) Plant Species Richness and Composition in a Trans-Himalayan Inner Valley of Manang District, Central Nepal. Himalayan Journal of Sciences, 4, 57-64. https://doi.org/10.3126/hjs.v4i6.983

[18] Wana, D. and Beierkuhnlein, C. (2009) The Relative Abundance of Plant Functional Types along Environmental Gradients in the Southwest Ethiopian Highlands. Journal of Tropical Ecology, 54-83.

[19] Rowe, N. and Speck, T. (2005) Plant Growth Forms: An Ecological and Evolutionary Perspective. New Phytologist, 166, 61-72. https://doi.org/10.1111/j.1469-8137.2004.01309.x

[20] Dalacho, H.D.W. (2009) Plant Species and Functional Diversity along Altitudinal Gradients, Southeast Ethiopian Highlands. Ph.D. Thesis, University of Bayreuth, Bayreuth, Germany.

[21] Baldocchi, D., Xu, L. and King, N. (2004) How Plant Functional Type, Weather, Seasonal Drought, and Soil Physical Properties Alter Water and Energy Fluxes of an Oak-Grass Savanna and an Annual Grassland. Agricultural and Forest Meterology, 123, 13-39. https://doi.org/10.1016/j.agrformet.2003.11.006

[22] Breshears, D.D. and Barnes, F.J. (1999) Interrelationships between Plant Functional Types and Soil Moisture Heterogeneity for Semiarid Landscapes within the Grassland/Forest Continuum: A Unified Conceptual Model. Landscape Ecology, 14, 465-478. https://doi.org/10.1023/A:1008040327508

[23] Cody, M.L. (1991) Niche Theory and Plant Growth Form. Vegetation, 97, 39-55.

[24] Bhattarai, K.R. and Vetaas, O.R. (2003) Variation in Plant Species Richness of Different Life Forms along a Subtropical Elevation Gradient in the Himalayas, East Nepal. Global Ecology and Biogeography, 12, 327-340. https://doi.org/10.1046/j.1466-822X.2003.00044.x

[25] Cingolani, A.M., Posse, G. and Collantes, M.B. (2005) Plant Functional Traits, Herbivore Selectivity and Response to Sheep Grazing in Patagonian Steppe Grasslands. Journal of Applied Ecology, 42, 50-59. https://doi.org/10.1111/j.1365-2664.2004.00978.x

[26] Klimesova, J., Dolezal, J., Dvorsky, M., De Bello, F. and Klimes, L. (2010) Clonal Growth Forms in Eastern Ladakh, Western Himalayas: Classification and Habitat Preferences. Folia Geobot, Springer.

[27] Klimes, L., Klimesova, J., Hendriks, R. and Groenendael, J. (1997) Clonal Plant Architectures: A Comparative Analysis of Form and Function. In: De Kroon, H. and Van Groenendael, J., Eds., The Ecology and Evolution of Clonal Plants, Backhuys Publishers, Leiden, 1-29.

[28] Raunkiaer, C. (1934) The Life Form of Plants and Statistical Plant Geography. The Clarendon Press, Oxford, 2-104.

[29] Grime, J.P. (2001) Plant Strategies, Vegetation Processes, and Ecosystem Properties. 2nd Edition, Wiley, Chichester, UK.

[30] Garnier, E., Lavorel, S., Ansquer, P., Castro, H., Cruz, P., Dolezal, J., Eriksson, O., Fortunel, C., Freitas, H., Golodets, C., Grigulis, K., Jouany, C., Kazakou, E., Kigel, J., Kleyer, M., Lehsten, V., Leps, J., Meier, T., Pakeman, R., Papadimitriou, M., Papa- 
nastasis, V.P., Quested, H., Quetier, F., Robson, M., Roumet, C., Rusch, G., Skarpe, C., Sternberg, M., Theau, J.P., Thebault, A., Vile, D. and Zarovali, M.P. (2007) Assessing the Effects of Land-Use Change on Plant Traits, Communities and Ecosystem Functioning in Grasslands: A Standardized Methodology and Lessons from an Application to 11 European Sites. Annals of Botany, 99, 967-985.

https://doi.org/10.1093/aob/mcl215

[31] Ryser, P. and Lambers, H. (1995) Root and Leaf Attributes Accounting for the Performance of Fast- and Slow-Growing Grasses at Different Nutrient Supply. Plant and Soil, 170, 251-265. https://doi.org/10.1007/BF00010478

[32] Xu, F., Guo, W., Wei, Y. and Wang, R. (2009) Leaf Morphology Correlates with Water and Light Availability: What Consequences for Simple and Compound Leaves? Progress in Natural Science, 19, 1789-1798. https://doi.org/10.1016/j.pnsc.2009.10.001

[33] Olivero, L.S. (2011) Functional Trait Approach to Assess the Ecological Processes of Drought Tolerance and Water Use Efficiency in Silvopastoral Systems of Rivas Department, Nicaragua. Master of Science Thesis, The Tropical Agricultural Research and Higher Education Center, Turrialba, Costa Rica, 74. 
Appendix. Name of the investigated plant species.

\begin{tabular}{|c|c|c|c|c|}
\hline S.N. & Name of the species & Family & Life form & Growth form \\
\hline 1 & Abies spectabilis (D. Don) Mirb. & Pinaceae & $\mathrm{P}$ & $\mathrm{T}$ \\
\hline 2 & Aconogonum molle (D. Don) H. Hara & Polygonaceae & $\mathrm{C}$ & S \\
\hline 3 & Alnus nepalensis D. Don & Betulaceae & $\mathrm{P}$ & $\mathrm{T}$ \\
\hline 4 & Anaphalis busua (Buch.-Ham. ex D. Don) DC. & Compositae & $\mathrm{He}$ & $\mathrm{H}$ \\
\hline 5 & Anaphalis triplinervis (Sims) C. B. Clarke & Compositae & $\mathrm{He}$ & $\mathrm{H}$ \\
\hline 6 & Androsace sarmentosa Wall. & Primulaceae & $\mathrm{He}$ & $\mathrm{H}$ \\
\hline 7 & Artemisia indica Willd. & Compositae & $\mathrm{C}$ & $\mathrm{H}$ \\
\hline 8 & Arundinaria maling Gamble & Graminae & $\mathrm{P}$ & S \\
\hline 9 & Aster flaccidus Bunge & Compositae & $\mathrm{He}$ & $\mathrm{H}$ \\
\hline 10 & Avena sativa $L$ & Graminae & Th & $\mathrm{H}$ \\
\hline 11 & Berberis aristata DC. & Berberidaceae & $\mathrm{P}$ & S \\
\hline 12 & Betula utilis D. Don & Betulaceae & $\mathrm{P}$ & $\mathrm{T}$ \\
\hline 13 & Bistorta amplexicaulis (D. Don) Greene & Polygonaceae & $\mathrm{He}$ & $\mathrm{H}$ \\
\hline 14 & Capsella bursa-pastoris (L.) Medik. & Brassicaceae & $\mathrm{He}$ & $\mathrm{H}$ \\
\hline 15 & Commelina maculata Edgew. & Commelinaceae & $\mathrm{He}$ & $\mathrm{H}$ \\
\hline 16 & Cotoneaster microphyllus Wall. ex Lindl. & Rosaceae & $\mathrm{C}$ & S \\
\hline 17 & Daphne bholua var. glacialis Buch.-Ham. ex D. Don & Thymelaceae & $\mathrm{P}$ & S \\
\hline 18 & Dipsacus inermis Wall & Dipsacaceae & $\mathrm{C}$ & $\mathrm{H}$ \\
\hline 19 & Elsholtzia fruticosa (D. Don) Rehder & Labiatae & $\mathrm{P}$ & $\mathrm{H}$ \\
\hline 20 & Eupatorium adenophorum Spreng. & Compositae & C & $\mathrm{H}$ \\
\hline 21 & Euphorbia sikkimensis Boiss. & Euphorbiaceae & $\mathrm{C}$ & $\mathrm{H}$ \\
\hline 22 & Fragaria indica Andrews. & Rosaceae & $\mathrm{He}$ & $\mathrm{H}$ \\
\hline 23 & Fragaria nubicola Lindl. ex Lacaita & Rosaceae & $\mathrm{He}$ & $\mathrm{H}$ \\
\hline 24 & Gaultheria fragrantissima Wall. & Ericaceae & $\mathrm{P}$ & S \\
\hline 25 & Geranium pratense L. & Geraniaceae & $\mathrm{He}$ & $\mathrm{H}$ \\
\hline 26 & Geum elatum Wall. ex G. Don & Rosaceae & $\mathrm{He}$ & $\mathrm{H}$ \\
\hline 27 & Hedera nepalensis K. Koch & Araliaceae & $\mathrm{He}$ & $\mathrm{H}$ \\
\hline 28 & Heracleum nepalense D. Don & Umbeliferae & $\mathrm{He}$ & $\mathrm{H}$ \\
\hline 29 & Impatiens urticifolia Wall. & Balsaminaceae & $\mathrm{He}$ & $\mathrm{H}$ \\
\hline 30 & Inula cappa (Buch.-Ham. ex D. Don) DC. & Compositae & $\mathrm{C}$ & S \\
\hline 31 & Iris clarkei Baker ex Hook. f. & Iridaceae & G & $\mathrm{H}$ \\
\hline 32 & Juniperus indica Bertol. & Cupressaceae & $\mathrm{P}$ & $\mathrm{T}$ \\
\hline 33 & Juniperus recurva Buch.Ham. ex D. Don & Cupressaceae & $\mathrm{P}$ & S \\
\hline 34 & Lonicera angustifolia Wall. ex DC. & Caprifoliaceae & $\mathrm{P}$ & S \\
\hline 35 & Lyonia ovalifolia (Wall.) Drude & Ericaceae & $\mathrm{P}$ & $\mathrm{T}$ \\
\hline 36 & Malaxis cylindrostachya (Lindl.) Kuntze & Orchidaceae & G & $\mathrm{H}$ \\
\hline
\end{tabular}




\section{Continued}

\begin{tabular}{|c|c|c|c|c|}
\hline 37 & Osbeckia stellata Buch.-Ham. ex D. Don & Melastomataceae & $\mathrm{P}$ & S \\
\hline 38 & Pedicularis siphonantha D.Don & Scrophulariaceae & $\mathrm{He}$ & $\mathrm{H}$ \\
\hline 39 & Phlomis rotata Benth. ex Hook. f. & Labiatae & $\mathrm{P}$ & $\mathrm{H}$ \\
\hline 40 & Pieris formosa (Wall.) D. Don & Ericaceae & $\mathrm{P}$ & $\mathrm{S}$ \\
\hline 41 & Pilea umbrosa Blume & Urticaceae & $\mathrm{C}$ & $\mathrm{H}$ \\
\hline 42 & Pinus wallichiana A. B. Jacks. & Pinaceae & $\mathrm{P}$ & $\mathrm{T}$ \\
\hline 43 & Plantago major L. & Plantaginaceae & $\mathrm{He}$ & $\mathrm{H}$ \\
\hline 44 & Potentilla fructicosa var. rigida $\mathrm{L}$. & Rosaceae & $\mathrm{He}$ & $\mathrm{H}$ \\
\hline 45 & Primula denticulata Sm. & Primulaceae & $\mathrm{He}$ & $\mathrm{H}$ \\
\hline 46 & Quercus semecarpifolia Sm. & Fagaceae & $\mathrm{P}$ & $\mathrm{T}$ \\
\hline 47 & Rhododendron arboreum Sm. & Ericaceae & $\mathrm{P}$ & $\mathrm{T}$ \\
\hline 48 & Rhododendron campanulatum D. Don & Ericaceae & $\mathrm{P}$ & $\mathrm{T}$ \\
\hline 49 & Rhododendron lepidotum Wall. ex G. Don & Ericaceae & $\mathrm{P}$ & S \\
\hline 50 & Rhododendron setosum D.Don & Ericaceae & $P$ & S \\
\hline 51 & Rosa sericea Lindl. & Rosaceae & $P$ & $\mathrm{~S}$ \\
\hline 52 & Roscoea purpurea Sm. & Zingeberaceae & G & $\mathrm{H}$ \\
\hline 53 & Rubus ellipticus Sm. & Rosaceae & $\mathrm{P}$ & $\mathrm{S}$ \\
\hline 54 & Rumex nepalensis Spreng. & Polygonaceae & $\mathrm{He}$ & $\mathrm{H}$ \\
\hline 55 & Salvia campanulata Wall. ex Benth. & Labiatae & $\mathrm{C}$ & $\mathrm{H}$ \\
\hline 56 & Saxifraga parnassifolia D. Don & Saxifragaceae & $\mathrm{He}$ & $\mathrm{H}$ \\
\hline 57 & Senecio cappa Buch.-Ham. ex D. Don & Compositae & $\mathrm{C}$ & $\mathrm{H}$ \\
\hline 58 & Senecio diversifolius Wall. ex DC Sene.div & Compositae & $\mathrm{C}$ & $\mathrm{H}$ \\
\hline 59 & Tsuga dumosa (D. Don) Eichler & Pinaceae & $\mathrm{P}$ & $\mathrm{T}$ \\
\hline 60 & Zanthoxylum armatum DC. & Rutaceae & $P$ & $\mathrm{~T}$ \\
\hline
\end{tabular}

Growth forms: T = Tree; $\mathrm{S}=$ Shrub; DS = Dwarf Shrub; H = Herb. Life forms: Th = Therophyte; He = Hemicryptophyte; $\mathrm{P}=$ Phanerophyte; $\mathrm{C}=$ Chameophyte; $\mathrm{G}=$ Geophyte. 